\title{
Evaluating The Performance of Nutrients Uptake Capabilities and Enzymatic Activities in The Different Green Manures
}

Farheen Solangi ( $\square$ feryssolangi@yahoo.com )

Chinese Academy of Agricultural Sciences

\section{Songjuan Gao}

Chinese Academy of Agricultural Sciences

Kashif Solangi

Jiangsu University

Weidong Cao

Chinese Academy of Agricultural Sciences

\section{Research Article}

Keywords: nutrient availability, soil enzymatic activities, $\mathrm{P}$ and $\mathrm{K}$ obtain, green manure crops

Posted Date: September 3rd, 2021

DOI: https://doi.org/10.21203/rs.3.rs-809633/v1

License: (a) (i) This work is licensed under a Creative Commons Attribution 4.0 International License. Read Full License 


\section{Abstract}

Winter green manure potentially uptake large amount of phosphorus $(P)$ and potassium $(K)$ from the soil. However, the mechanism underlying nutrient uptake in green manure varieties remain elusive. This study illustrates the $\mathrm{P}$ and $\mathrm{K}$ uptake potential in different leguminous and non-leguminous species through integrated approaches. The designed studies evaluated the 10 green manure crops included five leguminous species (i.e smooth vetch hairy vetch, common vetch, lathyrus sativus, and milk vetch) and five non-leguminous species (i.e February orchid, chinese radish, forage radish, rapeseed and ryegrass) were planted. Experimental results indicated that the smooth vetch had highest $\mathrm{P}$ and $\mathrm{K}$ uptake capabilities among all leguminous species. While, rapeseed and chinese radish greatly $\mathrm{P}$ and $\mathrm{K}$ obtain among all non-leguminous treatments. Therefore various species also affected soil $\mathrm{P}$ and $\mathrm{K}$ availability and soil enzymes. Soil enzymatic activities including phosphatase (150.7\%) and $\mathrm{N}$-acetylglucosaminidase (95.4\%) were elevated in lathryus sativus compared to the hairy vetch and common vetch respectively. The highest $\beta$-glucosidase (95.2\%) and leucine-aminopeptidase (107.6\%) activities accumulated in lathyrus sativus greater than the smooth vetch in all legumes species. In non-leguminous treatments phosphatase (500.5\%), $\beta$-glucosidase (424.4\%), and $\mathrm{N}$-acetylglucosaminidase $(256.3 \%)$ activities were improved in chinese radish as compared to the rapeseed. In constrast ryegrass was promoted greatest leucine-aminopeptidase activity by $182.7 \%$ higher than forage radish. However soil enzymes significanlty improve soil nutrient status. As a conclusion smooth vetch, rapeseed, and Chinese radish varieties have more $\mathrm{P}$ and $\mathrm{K}$ obtain capacity and forage radish could enhance soil enzyme activities. It is suggested these varieties might be a better choice in green manuring practice for improving nutrient management and soil nutrient quality in agro-ecosystems.

\section{Introduction}

Macro-nutrients phosphorus $(P)$ and potassium $(K)$ are essential for plant growth and development (Richardson et al. 2011a). P plays a vital role in transferring energy, and synthesize molecules such as phospholipids, adenosine triphosphate (ATP) with counterpart $\mathrm{K}$ which involves in physiological processes and activate several enzymatic activities (Prajapati, 2016; Shin, 2014; Vance, Uhde-stone, \& Allan, 2003). P mobility and $\mathrm{K}$ exchangeability in soil led to deficiencies and inhibit metabolism processes in plant (Qi and Spalding 2015). The P and K-efficient crop are main players in agricultural environment, including green manure crops which subsequently improve $\mathrm{P}$ and $\mathrm{K}$ availability in soil status (Jain et al. 2018). Green manure crops including legumes and non-legumes are essential for sustainable agriculture because they show a positive influence on the physic-chemical properties of soil (Eichler-löbermann et al., 2008). Additionally green manuring practice could increases $P$ bioavailability and $\mathrm{K}$ exchangeability which associate with soil mineral particles (Haynes and Mokolobate 2001; Mandal et al. 2003). Overall, the physicochemical properties of the soil, enhanced organic matter, maintained soil pH, reduction in soil erosion and nutrient cycles could be regulated through these practices (White et al. 2013). Enhanced nutrient uptake potential of a plant is associated with ultimate higher yield in low-nutrient conditions (Fageria et al., 2008). Plant root related traits of (green manure crops) leguminous and non-leguminous 
varieties involving $\mathrm{P}$ and $\mathrm{K}$ uptake could be varied in different species and their group; deeper root systems can prevent the scavenging of nutrient from deeper soil and potentially make it available for plant uptake in the soil surface (Richardson et al. 2011b). In plants, the available P have been found generally in orthophosphate $\left(\mathrm{PO}_{4}{ }^{3-}\right)$ form (Noack and Ester 2014). Some green manures cultivars for example white lupin (Lupines albus L.), peas (Pisum sativum L), chickpea (Cicer arietinum L.), and fava bean (Vicia faba), species have varied soil P content through various root systems (Li et al. 2003; Nuruzzaman et al. 2005). Also legume specie such as alfalfa (Medicago sativa), have deep root systems, which helps to add nutrients to the soil that are accessible to subsequent crops ( $L$ and Milkvetch 2020).

Green manure varieties provide favorable environmental conditions to soil (i.e., maintain the moisture content and increase the soil biological activities) (Ingver et al. 2019). Their roots and microbial proliferation secret extracellular enzymes into the soil which help to degrade the complex molecules into simple and enhancing mineralized nutrient to improve the soil organic matter (Grace et al. 2013). Enzymatic activities provide accurate determination of soil fertility and plant yield (Debnath et al. 2015). As soil enzyme activities mostly catalyze specific substrates thus specific soil microbiological activities could be linked with their reactions. However, the underlying property and catalyzing specific substrates, enzymes may not involve in whole nutrient cycle (Giagnoni and Renella 2011). Moreover, mineralization and dissolution by phosphatase enzymes could add significant organic $P$ fractions ( $L i$ et al. 2010). Extracellular enzyme activities (i.e., phosphatase $\mathrm{N}$-acetyl-glucosaminidase, Leucine-aminopeptidase and $\beta$-glucosidase ), which are related to $P, N$ and $C$ cycles, and they are significant for the soil quality. These enzymes could be change the soil biological modification (Caravaca et al. 2002). Chinese milk vetch winter legume have been broadly used for crop rotation mostly in rice field at southern parts of china (Samarajeewa et al., 2015). Recently, the cultivation of green manure crops has become a common practice to increase soil fertility in south china earlier; wide attentions have been given to $\mathrm{N}$ utilization in green manure species. However, limited information is present regarding $\mathrm{P}$ and $\mathrm{K}$ availability and activities of enzymes as influenced by the cultivation of various legume and non-legumes (green manure) crops under field conditions (Eichler et al. 2004; Kosteckas and Marcinkevi 2009).

The current study focused on screening of different leguminous and non-leguminous winter (green manure) species, as well as evaluated the performance of nutrients uptake efficiencies and nutrient availabilities among various species. Moreover, the assessment of different enzymatic activities and their interaction with soil properties which ultimate led to crop improvement.

\section{Materials And Methods \\ 2.1 Experimental site}

A site was located at southwest China Chengdu city, Sichuan province, (latitude $30^{\circ} 39^{\prime} \mathrm{N}$, lotitude $104^{\circ} 4^{\prime}$ E) with an altitude of $497 \mathrm{~m}$. The climatically zone of study site was subtropical, mean annual temperature was recorded $25^{\circ} \mathrm{C}$, and average annual precipitation $895.6 \mathrm{~mm}$ was selected for cultivation various green manure cultivars. The foundamental soil properties were given in Table 1. 
Table 1

The fundamental properties of soil

\begin{tabular}{|lll|}
\cline { 2 - 2 } & Parameter & Soil \\
\hline Soil organic matter $(\%)$ & 0.95 \\
\hline Total $\mathrm{N}\left(\mathrm{g} / \mathrm{kg}^{1)}\right.$ & 1.05 \\
\hline $\mathrm{NH}^{4+}\left(\mathrm{mg} / \mathrm{kg}^{1}\right)$ & 1.74 \\
\hline $\mathrm{NO}_{3}{ }^{-}\left(\mathrm{mg} / \mathrm{kg}^{-1}\right)$ & 2.7 \\
\hline Avaibale P $\left(\mathrm{mg} / \mathrm{kg}^{1}\right)$ & 18.9 \\
\hline Aavailable K $\left(\mathrm{mg} / \mathrm{kg}^{1}\right)$ & 130.5 \\
\hline $\mathrm{pH}(1: 2.5)$ & 7.8 \\
\hline
\end{tabular}

\subsection{Experimental Design and Growth Conditions}

An experimental design was based on a complete randomized block design contains ten green manure treatments. Green manure cultivars included leguminous species; smooth vetch (Vica.dasycarpa), hairy vetch (Vica villosa L.), common vetch (Vica sativa L.), lathyrus sativus (lathyrus. sativus), milk vetch ( $A$ Astragalus.sinicus L.), and non-leguminous species were February orchid (Orychophragmus violaceus L.), chinese radish (Raphanus sativus var. Longipinnatus) and forage radish, (Raphanus raphanistrum subsp.sativus), rapeseed (Baricca.napus) and ryegrass (Lolium perenne L.) were planted for assessment. Each treatment (vareity) was contain four replicates with $4 \mathrm{~m}^{2}$ per plot and total experimental unit areas were used $144 \mathrm{~m}^{2}$. No any fertilizer was used in the growing period of different crops. Legumious and non-leguminous varieties were seeded on 11th November 2017.

\subsection{Soil Sampling and Determination}

Sub-surface samples were collected from a depth $0-20 \mathrm{~cm}$ from each plot and divided into three different parts. One part of fresh samples was quikly kept at $-80 \mathrm{C}$ for enzymes analysis, and the second part was preserved at $-4^{\circ} \mathrm{C}$ for soil moisture content and mineral nitrogen $\left(\mathrm{NH}_{4}{ }^{+}, \mathrm{NO}_{3}{ }^{-}\right)$. The third portion drying and sieve from $0.25 \mathrm{~mm}$ for total nitrogen and soil organic matter analysis.

The fresh soil sub-samples were used to analyze mineral $\mathrm{N}$ which extracted with 2 Molar solution of potassium chloride $(\mathrm{KCl})$ and shaken for 1 hour to using a continuous flow analyzer (Seal AA3, Norderstedt, Germany). The total $\mathrm{N}$ contents were analyzed by the Kjeldahl method digested with concentrated sulfuric acid $\left(\mathrm{H}_{2} \mathrm{SO}_{4}\right)$ (Nelson and Sommers 1973). Soil organic were determined by Walkley black method (Nelson 1996). Soil pH was maintained as 1:2.5 soil/water ratios using a pH meter (Mettler Toledo 320-S, Shanghai Bante Instrument Co., Ltd., Shanghai, China). The Olsen phosphorus treated with a $0.5 \mathrm{M}$ sodium bicarbonate and analyzed by using a visible light spectroscopic analysis of a blue 
coloured (UV-VIS spectrophotometer, Model UV-2100, Shimadzu, Kiyoto, Japan). Available potassium analyzed through flame photometer using $5 \mathrm{~g}$ soil and $1 \mathrm{M}$ ammonium acetate (Station 1962).

\subsection{Plants Nutrient analysis}

At the flowering stage, all green manures were harvested, and separated shoots and roots of plant. Shoots dry biomass were weighted and then were dried in an oven at $65^{\circ} \mathrm{C}$ for 72 hours, after that grind and kept for nutrients analyses. The N, P and K contents of plants were determined by Kjeldahl digestion method (Nelson and Sommers 1973), the by molybdovanadate method (Soonl and Kalra 1994), and the flame photometry (Station 1962), respectively.

\subsection{Enzymatic Activities Analysis}

Enzymatic activities such as Phosphatase, N-acetyl-glucosaminidase, $\beta$-glucosidase, and Leucineaminopeptidase were measured as previously described method (Kurola and Salkinoja-salonen 2004; Deforest 2009). For analysis $1 \mathrm{~g}$ of fresh overnight incubated $\left(24^{\circ} \mathrm{C}\right)$ soil was put into a $100 \mathrm{~mL}$ polypropylene strainer tube, and it was treated with 50 moles per liter of $50 \mathrm{mM}$ sodium acetate buffer and regulate for $1 \mathrm{mint}$ then the sample suspension was dispensed into a $500 \mathrm{~mL}$ beaker. Also, $50 \mathrm{~mL}$ of acetate buffer was use to washed the centrifuge tube and mixture was put into the same beaker. $A$ magnetic stirred was used to mix a suspension solution. The buffer solution, $10 \mu \mathrm{M}$ references and 200 $\mu \mathrm{M}$ substrates (Table 2), were distributed in a black 96-well microplate to maintained the capacity and order fixed (Saiya-Cork et al. 2002). The micro-plates were closed and place in the incubated at $25 \circ \mathrm{C}$ for 4 hours and the fluorescence quantified using a micro-plate fluorometer (Scientific Fluoroskan Ascent FL, Thermo) with excitation $365 \mathrm{~nm}$ and emission $450 \mathrm{~nm}$ filters (Saiya-Cork et al. 2002). The activities of enzymes were expressed in units of in $\mathrm{nmol} \mathrm{h} \mathrm{h}^{-1} \mathrm{~g}^{-1}$.

Table 2

Enzymes assessed in the legume and non-legume crops and enzymes commission number (EC) and consistent substrate ( yphenylalanine, 4-MUB = 4-methylumbelliferyl).

\begin{tabular}{|lll|}
\hline Enzymes & Substrate & EC \\
\hline Phosphatase & 4-MUB-phosphatase & 3.1 .3 .1 \\
\hline B-Glucosidase & 4-MUB- $\beta$-D-glucoside & 3.2 .1 .21 \\
N-acetyl-glucosaminidase & 4-MUB-N-acetyl-b-D-glucosaminide & 3.2 .1 .30 \\
\hline Leucine-aminopeptidase & L-Leucine-7-amino-4-methylcoumarin & 3.4 .11 .1 \\
\hline
\end{tabular}

\section{Statistical Analyses}

The collected data were used for analysis of variance (ANOVA) using IBM SPSS Statistics version 20.0, (Corp., Armonk, NY, USA). Analysis the significant differences between various species of green manure 
crops and their effects on soil properties followed by Duncan's tests at $P<0.05$ were used to asses to varieties difference. The correlation between $\mathrm{P}$ and $\mathrm{K}$ obtain and soil properties were used to base on Pearson's correlation coefficients using * and $* *$ to specify the $p<0.05$ and $p<0.01$ significant levels. The enzyme analysis graphs were prepared by using Origin Pro. 9.0 (Northampton, MA, USA). The Principle component analysis (PCA) and redundancy analysis (RDA) were carried out by using CONOCO (Canoco for Windows 4.5, Microcomputer Powering., Willis, TX, USA) at the significance level $p<0.05$; determine the correlation among various treatments, soil properties and soil enzyme activities.

\section{Results}

\subsection{Legumes Shoot Biomass and $\mathrm{P}$ and $\mathrm{K}$ absorption}

Legume shoot dry biomass production and $\mathrm{P}$ and $\mathrm{K}$ absorption (uptake) capacity showed significant difference among all treatments (Table 3 ). However, the common vetch was produced highest biomass production by $151.0 \%$ compared to milk vetch variety. The percentages dry biomass production of other legume treatments were increased in the following direction: smooth vetch hairy vetch and lathryus sativus i.e., $99.2,100.3,112.9 \%$ respectively, compared to the milk vetch. The smooth vetch had highest $P$ and K uptake abilities by 120.4 and $171.9 \%$ greater than milk vetch treatment. The lowest P (64.1\%) and $\mathrm{K}(104.0 \%)$ uptakes were observed in lathryus sativus, when compared to the milk vetch.

Table 3

Shoot dry biomass $\left(\mathrm{g} / \mathrm{m}^{2}\right)$, and $\mathrm{P}, \mathrm{K}$ absorption $\left(\mathrm{g} / \mathrm{m}^{2}\right)$ in different legumes

\begin{tabular}{|llll|}
\hline Legumes varieties & Shoot biomass $\left(\mathrm{g} / \mathrm{m}^{2}\right)$ & P absorption $\left(\mathrm{g} / \mathrm{m}^{2}\right)$ & K absorption $\left(\mathrm{g} / \mathrm{m}^{2}\right)$ \\
\hline Smooth vetch & $42.8 \pm 1.34 \mathrm{a}$ & $0.10 \pm 0.01 \mathrm{a}$ & $1.07 \pm 0.04 \mathrm{a}$ \\
\hline Hairy vetch & $43.1 \pm 4.80 \mathrm{a}$ & $0.09 \pm 0.01 \mathrm{a}$ & $0.83 \pm 0.08 \mathrm{~b}$ \\
\hline Common vetch & $54.0 \pm 4.2 \mathrm{a}$ & $0.09 \pm 0.00 \mathrm{a}$ & $0.93 \pm 0.09 \mathrm{ab}$ \\
\hline Lathryus sativus & $45.8 \pm 2.04 \mathrm{a}$ & $0.08 \pm 0.01 \mathrm{~b}$ & $0.81 \pm 0.03 \mathrm{~b}$ \\
\hline Milk vetch & $21.5 \pm 2.62 \mathrm{~b}$ & $0.05 \pm 0.01 \mathrm{~b}$ & $0.39 \pm 0.04 \mathrm{c}$ \\
\hline
\end{tabular}

Legume species i.e., smooth vetch hairy vetch, common vetch, lathryus sativus and milk vetch, are tested. The different letter shows significant variance at $(p<0.05)$ by Duncan's tests.

\subsection{Non-legumes shoot biomass and $\mathrm{P}$ and $\mathrm{K}$ absorption}

The dry biomass production and $\mathrm{P}, \mathrm{K}$ absorption ability of non-legumes cultivar also showed significant results among all different treatments (Table 4). The greatest biomass production and $\mathrm{P}$ uptakes increased in rape seed by $391.3 \%$, and $463.6 \%$ respectively, when compared to the february orchid. The minimum dry biomass ratio and $\mathrm{P}$ uptake were found in ryegrass compared to february orchid. While 
highest $\mathrm{K}$ uptakes among non-leguminous species was recored in chinese radish by $556.9 \%$ compared to february orchid. The minimum $\mathrm{K}$ uptake was seen in ryegrass i.e., $234.8 \%$ higher than february orchid.

Table 4

Shoot dry biomass $\left(\mathrm{g} / \mathrm{m}^{2}\right), \mathrm{P}$ and $\mathrm{K}$ absorption $\left(\mathrm{g} / \mathrm{m}^{2}\right)$ in various non-legumes

\begin{tabular}{|llll|}
\hline Non-legumes Species & Dry biomass $\left(\mathrm{g} / \mathrm{m}^{2}\right)$ & P absorption $\left(\mathrm{g} / \mathrm{m}^{2}\right)$ & K absorption $\left(\mathrm{g} / \mathrm{m}^{2}\right)$ \\
\hline February orchid & $6.11 \pm 1.44 \mathrm{c}$ & $0.01 \pm 0.00 \mathrm{~b}$ & $0.12 \pm 0.04 \mathrm{c}$ \\
\hline Chinese radish & $34.1 \pm 4.02 \mathrm{~b}$ & $0.07 \pm 0.14 \mathrm{a}$ & $0.82 \pm 0.17 \mathrm{a}$ \\
\hline Forage radish & $34.0 \pm 2.34 \mathrm{~b}$ & $0.06 \pm 0.01 \mathrm{a}$ & $0.73 \pm 0.07 \mathrm{a}$ \\
\hline Rape seed & $46.0 \pm 3.32 \mathrm{a}$ & $0.08 \pm 0.01 \mathrm{a}$ & $0.76 \pm 0.08 \mathrm{a}$ \\
\hline Ryegrass & $27.1 \pm 1.06 \mathrm{~b}$ & $0.03 \pm 0.00 \mathrm{~b}$ & $0.42 \pm 0.04 \mathrm{~b}$ \\
\hline
\end{tabular}

Non- legumes species i.e., February orchid, Chinese radish, forage radish, rape seed and rye grass are tested. The different letter shows significant variance at $(p<0.05)$ by Duncan's tests.

\subsection{Effects of legumes on soil available $\mathrm{P}$ and $\mathrm{K}$ Contents}

Table 5 indicates that significant changes in the soil available $\mathrm{P}$ and $\mathrm{K}$ content among all leguminous varieties. The maximum soil P content was found in common vetch by $205.7 \%$ as compared to the hairy vetch. Moreover, the lowest P content observed in smooth vetch i.e. 50\% higher than hairy vetch. Whereas, higher soil available $\mathrm{K}$ contents developed by following order: hairy vetch, lathryus sativus, milk vetch and smooth vetch were $17.2 \%, 9.4 \%, 7.5 \%$ and $2.0 \%$ respectively, in different leguminous treatments higher than common vetch.

Table 5

Influence of various leguminous species on soil available $\mathrm{P}$ and available K contents (average \pm standard error)

\begin{tabular}{|lll|}
\hline legumes varieties & Available $\mathrm{P}\left(\mathrm{mg} / \mathrm{kg}^{1}\right)$ & Available K $\left(\mathrm{mg} / \mathrm{kg}^{1}\right)$ \\
\hline Smooth vetch & $11.3 \pm 0.57 \mathrm{bc}$ & $110.9 \pm 3.5 \mathrm{~cd}$ \\
\hline Hairy vetch & $7.50 \pm 0.56 \mathrm{c}$ & $127.5 \pm 2.7 \mathrm{a}$ \\
\hline Common vetch & $22.9 \pm 1.85 \mathrm{a}$ & $108.7 \pm 1.2 \mathrm{~d}$ \\
\hline Lathryus sativus & $14.9 \pm 1.60 \mathrm{~b}$ & $118.9 \pm 1.6 \mathrm{~b}$ \\
\hline Milk vetch & $15.4 \pm 1.59 \mathrm{~b}$ & $116.7 \pm 2.2 \mathrm{bc}$ \\
\hline
\end{tabular}

Legumes i.e., smooth vetch hairy vetch, common vetch, lathryus sativus and milk vetch, are tested. The different letter shows significant changes at $(p<0.05)$ by Duncan's tests. 


\subsection{Effects of non-legumes on soil available $P$ and $K$ Contents}

Significant modifications were observsed in soil available $\mathrm{P}$ and $\mathrm{K}$ content among all non-leguminous cultivar (Table. 4). The soil available P content in variuos non-leguminous treatments were higher than forage radish. The available soil $P$ was developed by chinese radish and february orchid i.e., $103.4 \%$ and $72.2 \%$ repectively, compared to the forage radish. However, among all species maximum soil available $\mathrm{K}$ content was increased in the February orchid by $16.9 \%$ greater than the rape seed. While, lower soil K content was improve in other non- legume vareities i.e., $10.9 \%, 4.7 \%$, and $2.7 \%$ in ryegrass, chinese radish, and forage radish compared to rape seed variety.

Table 6

Influence of different of non-leguminous varieties on soil available $\mathrm{P}$ and available $\mathrm{k}$ contents I (average \pm standard error)

\begin{tabular}{|lll|}
\hline Non-legumes varieties & Available P $\left(\mathbf{m g} / \mathbf{k g}^{1}\right)$ & Available K $\left(\mathbf{m g} / \mathrm{kg}^{1}\right)$ \\
\hline February orchid & $21.4 \pm 2.59 \mathrm{a}$ & $132.0 \pm 2.1 \mathrm{a}$ \\
\hline Chinese radish & $25.2 \pm 2.36 \mathrm{a}$ & $118.2 \pm 1.8 \mathrm{C}$ \\
\hline Forage radish & $12.4 \pm 0.39 \mathrm{~b}$ & $116.0 \pm 0.6 \mathrm{C}$ \\
\hline Rape seed & $14.6 \pm 0.12 \mathrm{~b}$ & $112.9 \pm 2.1 \mathrm{c}$ \\
\hline Ryegrass & $14.4 \pm 0.21 \mathrm{~b}$ & $125.2 \pm 2.0 \mathrm{~b}$ \\
\hline
\end{tabular}

Non- legumes i.e., February orchid, Chinese radish, forage radish, rape seed and rye grass are tested. The small letter specifies significant variance at $(p<0.05)$ by Duncan's tests.

\subsection{Influence of legumes varieties on soil Enzymes}

Different leguminous crops significantly influenced $(p<0.05)$ on various extracellular enzymes phosphatase (Phos), N-acetylglucosaminidase (NAG), $\beta$-glucosidase (BG), and leucine-aminopeptidase (LAP) activities (Fig. 1). However, the lathryus sativus stimulated greatest phosphates activities by $150.7 \%$ compared to the hairy vetch and $\mathrm{N}$-acetylglucosaminidase activities by $95.4 \%$ compared to the common vetch. The highest $\beta$-glucosidase and leucine-aminopeptidase activities were accumulated in lathyrus sativus i.e., $95.2 \%$, and $107.6 \%$ respectively compared to the smooth vetch. While, minor variations were also found in other legumes to different enzyme activities.

\subsection{Influence of non-legumes varieties on soil Enzyme}

However, various non-leguminous treatments also showed significant modifications $(p<0.05)$ on different enzymes i.e., phosphatase (Phos), N-acetylglucosaminidase (NAG), $\beta$-glucosidase (BG), and leucine-aminopeptidase (LAP) activities (Fig. 2). The greatest phosphatase, (500.5\%), $\beta$-glucosidase (424.4\%), and $\mathrm{N}$-acetylglucosaminidase (256.3\%), enzyme activities were developed in Chinese radish 
compared to the rapeseed. In contrast, the highest leucine-aminopeptidase activity was recorded in ryegrass by $182.7 \%$ compared to the forage radish. While the lowest phosphatase, $\beta$-glucosidase activities were observed in forage radish only $49.7 \%$ and $37.5 \%$ higher than rape seed. The lower leucineaminopeptidase activities were found in February orchid by $35.6 \%$ higher than the forage radish.

\subsection{Interaction between plants $\mathrm{P}$ and $\mathrm{K}$ absorption and Soil Properties}

The Pearson correlation $(r)$ analysis demonstrated that plant $\mathrm{P}$ and $\mathrm{K}$ significantly correlates with soil properties (Table 7). The plant $\mathrm{P}$ absorption significantly related with soil ammonium $\left(\mathrm{NO}_{3-}\right)$ and available $K,\left(r=0.400^{* \star}, 0.333^{*}\right)$ respectively, while plant $\mathrm{K}$ uptake also showed a significant positive correlation with soil ammonium $\left(\mathrm{NO}_{3-}\right)$ and soil available $\mathrm{K}\left(\mathrm{r}=0.561^{\star \star}, 0.546^{* *}\right)$. However, nonsignificant correlations were found between other soil properties and $\mathrm{P}$ and $\mathrm{K}$ uptake of plant.

Table 7

Pearson correlations $(r)$ among nutrient $(P, K)$ uptake and soils property

\begin{tabular}{|c|c|c|c|c|c|c|c|c|}
\hline Parameters & K uptake & SOM & $\mathrm{TN}$ & $\mathrm{NH}_{4+}$ & $\mathrm{NO}_{3}^{-}$ & AP & AK & $\mathrm{pH}$ \\
\hline P uptake & 0.926 ** & $0 . .051$ & 0.186 & 0.45 & $0.400 * *$ & -0.184 & $0.561^{\star \star}$ & -0.121 \\
\hline K uptake & 1 & 0.105 & 0.074 & 0.011 & $0.333^{\star}$ & -0.183 & 0.546 ** & -0.156 \\
\hline SOM & & 1 & -0.297 & $0.502^{\star \star}$ & 0.236 & 0.281 & 0.025 & -0.112 \\
\hline TN & & & 1 & -0.257 & 0.163 & -0.229 & -0.051 & -0.187 \\
\hline $\mathrm{NH}_{4+}$ & & & & 1 & 0.173 & 0.254 & -0.051 & -0.037 \\
\hline $\mathrm{NO}_{3-}$ & & & & & 1 & $-0.340 *$ & 0.117 & $-0.327 *$ \\
\hline AP & & & & & & 1 & -0.084 & -0.217 \\
\hline \multirow[t]{2}{*}{ AK } & & & & & & & 1 & -0.135 \\
\hline & & & & & & & & 1 \\
\hline
\end{tabular}

Note : Soil organic matter (SOM), total nitrogen ( $\mathrm{TN})$, ammonia $\left(\mathrm{NH}_{4+}\right)$, nitrite $\left(\mathrm{NO}_{3-}\right)$ available phosphorus (AP) (available potassium), and pH (soil pH)

\subsection{Relationship between soil Enzymes Activities and Soil Properties}

The redundancy analysis (RDA) presented that the both axes explained $26.6 \%$ and $4.8 \%$ variation for enzymes activity and soil properties (Fig. 3). Both canonical axes indicated that $53.8 \%$ and $51.1 \%$ respectively of the total differences between enzymatic activities and soil properties. The left upper corner of the second axis of RDA was correlated to the enzyme activities. The activities of soil enzymes have 
shown a negtive significant relationships with SOM $(F=4.2, p<0.026), \operatorname{AP}(F=3.6, p<0.04)$, respectively. Non-significant correlations were seen between soil enzymes and other soil properties.

\subsection{Relationship among Different Species and Soil Properties}

The Principal Component Analysis (PCA) indicated a clear difference among different legumes and nonlegume treatments and soil properties (Fig. 3). The two PCA axes contributed $82.2 \%$ and $12.1 \%$, respectively of the variation between legumes and non-legumes crops and soil properties. The first axis of PCA was related to the high concentration of $\mathrm{SOM}, \mathrm{NH}^{4+}$ and available $\mathrm{P}$ with different species followed by legumes: common vetch, lathyrus sativus, and non-legumes included Chinese radish and february orchid. The content of total $\mathrm{N}$ and soil available $\mathrm{K}$ concentration correlated to various legume species i.e., smooth vetch, milk vetch, and non-legume included ryegrass treatments.

\section{Discussion}

\subsection{Plants and Soil Nutrient capacities}

The experimental results examined nutrients such as $\mathrm{P}$ and $\mathrm{K}$ absorption capacities in various legume and non-legume crops and its effect on available $\mathrm{P}$ and $\mathrm{K}$ contents of soil. However, the modifications were recorded in shoot dry biomass and $\mathrm{P}$ and $\mathrm{K}$ absorption abilities among all leguminous and nonleguminous species. In our study, legume's variety common vetch was produced greater biomass and smooth vetch had highly $\mathrm{P}$ and $\mathrm{K}$ uptake ability as compare with other legumes. The rape seed have highest dry biomass and $\mathrm{P}$ uptake among all non-legumes species (Table 3,4). According current results the higher biomass could reflect nutrients uptake abilities in different varieties, as well $\mathrm{P}$ and $\mathrm{K}$ uptakes of smooth vetch (legume) and rapeseed (non-legume) related to root physiological traits. The study by (Billard et al. 2014) supported to present experimental results that rapeseed obtained the highest amount of nutrients in their shoots. Furthermore, many previous studies demonstrated that roots traits of green manure crops associated to $\mathrm{P}$ and $\mathrm{K}$ uptake which also depended on their groups and families and extensive root systems beneficial for scavenge nutrient from deeper soil, and potentially make it available for plant uptake (Li et al. 2003; Nuruzzaman et al. 2005; Richardson et al. 2011b). Root considered as a major factor for the above-ground plant growth, nutrient takes from below ground soil, root faces a large number of soil environmental problems (Sial et al. 2019). Moreover, nutrient ( $P$ and $K$ ) uptake of plants by mass flow and diffusion are also important, which take place in the root systems and beneficial for the $P$ and K transport to the higher plant parts (Casper and Jackson 1997; Lynch 2007).

However, the soil available $\mathrm{P}$ and $\mathrm{K}$ content also affected by various (green manure) leguminous and nonleguminous treatments (Table 3,4). The higher available $\mathrm{P}$ content recorded in smooth vetch in (legume specie) and in Chinese radish (non-legume specie) in all experimental treatments (Table 3). Current results related with previous studies where higher soil $\mathrm{P}$ made available by forage radish (White and Weil 2011). Green manure crops have ability to release P-solubilizing compounds in to the soil through their 
unique root mechanisms, that could be improved soil nutrients availability for plant (Hammond and White 2008). Moreover, when legume root interacts with soil microbes and release organic compounds into the soil status, that could enhanced the $\mathrm{P}$ and $\mathrm{K}$ availability (Bünemann et al. 2004; Balota et al.

2014). Along with soil $P$ different species, were also effect on soil $K$ availability (Table 5,6$)$. Similar results were also recorded in previous studies, where green manure largely contribute to K availability (Sujatha et al. 2017). Moreover, when root interacts with microbes could be released organic acids into the rhizosphere soil, and it might be enhance the $\mathrm{P}$ and $\mathrm{K}$ availability (Bünemann et al. 2004; Balota et al. 2014).

\subsection{Soil Enzyme Activities}

Various leguminous and non-leguminous species of green manure could stimulate the microbial activities which could be the caused to enhance the extracellular enzymes in soil. Present results showed different enzyme activities influenced by leguminous treatments and non-leguminous treatments (Fig. 1, 2). The lathryus staivus promote various enzymes activities among all legume species. ). Similarities were observed another study, that the fava bean ( $V$. faba) and vetches (Vicieae) were promoting a higher phosphatase activity in a separate field study (Maltais-Landry and Frossard 2015). Previous studies demonstrated that phosphatase activity develops in the soil through legume roots which significantly increased available $P$ in plant (Makoi et al. 2010). It is also sustained by another study which shows that the red clover have increase more $\beta$-glucosidase activity (Piotrowska-Długosz and Wilczewski 2014; Mukumbareza et al. 2015). This study showed that Chinese radish stimulate various hydrolytic enzymes activity among the non-legumes treatment. The current results are agreed with an earlier study, the higher acid phosphatase activity were found in radish (R. Sativus) (Kunze et al. 2011). However leguminous and non-leguminous (green manure) included radishes which belongs to Brassicaceae family they have several unique characteristics, for example, high root density, root exudations, and symbiosis with mycorrhiza (White and Weil 2010). Additionally, in present research lathyrus sativus and hairy vetch also increase $\mathrm{N}$-cycle related enzymes $\mathrm{N}$-acetyl-glucosaminidase and Leucine-aminopeptidase activities. The leguminous crops not only involves in $\mathrm{N}$-cycle and provide high rate of rate of $\mathrm{N}$ content in the soil but also enhanced enzyme activities (Roldán et al. 2003). Enzymes are the active pool for $\mathrm{N}$ modification in soil status and $\mathrm{N}$-degrading enzymes will effects on $\mathrm{N}$ availability of soil (Yang et al. 2012).

Previous studies demonstrated that phosphatase activity develops in the soil through legume roots which significantly increased available in plant (Makoi et al. 2010). According to earlier study, the higher acid phosphatase activity were found in radish (R. Sativus) (Kunze et al. 2011). However, green manures included forage radish which belongs to Brassicaceae family they have several unique characteristics (White and Weil 2010). Some plant of Brassicaceae family have glucosinolates in their tissue, which are beneficial for hydrolyzed the soil enzyme activities (Vierheilig et al. 2000; Trust 2014). It is also sustained by another research, presenting that in $T$. pratense $L$, and $B$. napus leguminous species promote the activity of $\beta$-glucosidase (Piotrowska-Długosz and Wilczewski 2014; Mukumbareza et al. 2015). Furthermore, in our study lathyrus sativus and hairy vetch also increase $\mathrm{N}$-cycle related enzymes $\mathrm{N}$-acetylglucosaminidase and Leucine-aminopeptidase activities. The amount of $\mathrm{N}$ content in the soil through 
legume varieties not only contains in $\mathrm{N}$-cycle but also increases different rate of enzymatic activities (Roldán et al. 2003). Activities of soil enzymes are the active factor for $\mathrm{N}$ transformation in soil and changes in the activities of $\mathrm{N}$-degrading enzymes will affect the soil $\mathrm{N}$ availability (Yang et al. 2012).

\subsection{Relationship between plant and soil nutrient and Enzymes}

The study exposed that changes in the soil properties could effects on soil enzyme activities under different leguminous and non-leguminous treatments. The redundancy analysis (RDA) has shown soil enzymatic activities positively correlated with soil properties (SOM and AP) (Fig. 3). The activities of soil enzyme can perform as indicators to associate soil organic matter, in the many cases, soil enzymes when interacting with the microbial community which potentially decomposed SOM and leads to an increase nutrient availability in soil(Sinsabaugh et al. 2005). Soil enzyme contributes to alterations in substrate availability of essential nutrients and activities of enzymes are closely related to the changes in chemical properties (Wallenius et al. 2011; Cenini et al. 2017). Additionally, the phosphate enzyme activity is related with $\mathrm{P}$ mineralization in soils plays a key role in $\mathrm{P}$ cycling that promote plant development (Margalef et al. 2017). The principle component analysis (PCA) showed green manure species correlated with soil properties, while earlier research showed green manure crops play a significant role to maintain the soil fertility status (Fageria et al. 2005). The affected of soil properties by various species due to their shoots and roots traits related to high nutrient concentration under the low-fertility condition (Hallama 2018). Soil enzymes are major element for biological modification in soil (Caravaca et al. 2002; Giagnoni and Renella 2011).

\section{Conclusion}

An accumulative result from current study indicates the highest biomass production of common vetch, smooth vetch and rapeseed had highest $\mathrm{P}$ and $\mathrm{K}$ uptake abilities were found due to their particular root morphological mechanisms. In the green manuring phase legumes that have smooth vetch and nonlegumes rapeseed might be better choice to improve the $\mathrm{P}$ management in rice field southwest china, which is useful for crop cultivation and agro-ecosystem. Green manuring practice can also decrease fertilizer needed for next crop production. Whereas, forage radish increased enzymatic activities which relates to their unique characteristics revealed that cultivation of radish species could improve soil quality at green manuring, which is a cheap and valuable practice. Additionally, the study has further requirements to explain the impact of leguminous and non-leguminous crop to soil microbial communities and roots mechanisms which improve soil fertility.

\section{Declarations}

\section{Ethical approval}

It is certified that all the authors have complied with ethical requirements. 


\section{Consent to participate}

All the authors participated equally in writing of the manuscript.

\section{Consent to publish}

This manuscript is neither submitted anywhere nor under consideration for publication elsewhere.

\section{Authors contributions}

Conceptualization, Farheen Solangi; methodology, Farheen Solangi and Songjuan Gao; validation, Kashif Solangi; formal analysis, Farheen Solangi and Kashif Solangi; investigation, Songjuan Gao and Weidong Cao; data curation, Farheen Solangi and Weidong Cao; writing-original draft preparation, Farheen Solangi; writing-review and editing, Kashif Solangi; supervision, Songjuan Gao and Weidong Cao. All authors read and approved the final manuscript."

\section{Funding}

This manuscript received no external funding.

\section{Competing Interest}

The authors declare that they have no known competing financial interests or personal relationships that could have appeared to influence the work reported in this manuscript.

\section{Availability of data and material}

All data generated or analyzed during this study are included in this manuscript.

\section{References}

1. Balota EL, Calegari A, Nakatani AS, Coyne MS (2014) Benefits of winter cover crops and no-tillage for microbial parameters in a Brazilian Oxisol: A long-term study. Agric Ecosyst Environ 197:31-40. https://doi.org/10.1016/j.agee.2014.07.010

2. Billard V, Etienne P, Jannin L et al (2014) Two Biostimulants Derived from Algae or Humic Acid Induce Similar Responses in the Mineral Content and Gene Expression of Winter Oilseed Rape (Brassica napus L.). J Plant Growth Regul 33:305-316. https://doi.org/10.1007/s00344-013-9372-2

3. Bünemann EK, Smithson PC, Jama B et al (2004) Maize productivity and nutrient dynamics in maizefallow rotations in western Kenya. Plant Soil 264:195-208.

https://doi.org/10.1023/B:PLSO.0000047749.43017.fd

4. Caravaca F, Masciandaro G, Ceccanti B (2002) Land use in relation to soil chemical and biochemical properties in a semiarid Mediterranean environment. Soil Tillage Res 68:23-30. https://doi.org/10.1016/S0167-1987(02)00080-6 
5. Casper BB, Jackson RB (1997) Plant competition underground. Annu Rev Ecol Syst 28:545-570. https://doi.org/10.1146/annurev.ecolsys.28.1.545

6. Cenini V, Fornara D, Mcmullan G et al (2017) Linkages between extracellular enzyme activities and the carbon and nitrogen content of grassland soils To cite this version: HAL Id : hal-01632569. https://doi.org/10.1016/j.soilbio.2016.02.015

7. Debnath S, Patra AK, Ahmed $\mathrm{N}$ et al (2015) Assessment of microbial biomass and enzyme activities in soil under temperate fruit crops in north western himalayan region. J soil Sci plant Nutr 15:0-0. https://doi.org/10.4067/S0718-95162015005000059

8. Deforest JL (2009) Soil Biology \& Biochemistry The influence of time, storage temperature, and substrate age on potential soil enzyme activity in acidic forest soils using MUB-linked substrates and L -DOPA. Soil Biol Biochem 41:1180-1186. https://doi.org/10.1016/j.soilbio.2009.02.029

9. Eichler-löbermann B, Köhne S, Kowalski B et al (2008) Effect of Catch Cropping on Phosphorus Bioavailability in Comparison to Organic and Inorganic Fertilization Effect of Catch Cropping on Phosphorus Inorganic Fertilization. 4167:. https://doi.org/10.1080/01904160801926517

10. Eichler B, Caus M, Schnug E, Köppen D (2004) Soil acid and alkaline phosphatase activities in regulation to crop species and fungal treatment. Landbauforsch Völkenrode 54:1-5

11. Fageria NK, Baligar VC, Bailey BA (2005) Role of Cover Crops in Improving Soil and Row Crop Productivity. Commun Soil Sci Plant Anal 36:2733-2757. https://doi.org/10.1080/00103620500303939

12. Fageria NK, Baligar VC, Li YC et al Journal of Plant Nutrition. https://doi.org/10.1080/01904160802116068

13. Giagnoni L, Renella G (2011) Role of Phosphatase Enzymes in Soil Chap. 9 Role of Phosphatase Enzymes in Soil. https://doi.org/10.1007/978-3-642-15271-9

14. Grace B, Samantha W, Weintraub R, Sinsabaugh RL (2013) Ecoenzymatic stoichiometry of microbial nutrient acquisition in tropical soils. https://doi.org/10.1007/s10533-013-9849-x

15. Hallama M (2018) Hidden miners - the roles of cover crops and soil microorganisms in phosphorus cycling through agroecosystems

16. Hammond JP, White PJ (2008) Sucrose transport in the phloem: integrating root responses to phosphorus starvation. 59:93-109. https://doi.org/10.1093/jxb/erm221

17. Haynes RJ, Mokolobate MS (2001) Amelioration of Al toxicity and P deficiency in acid soils by additions of organic residues: A critical review of the phenomenon and the mechanisms involved. Nutr Cycl Agroecosystems 59:47-63. https://doi.org/10.1023/A:1009823600950

18. Ingver A, Tamm Ü, Tamm I et al (2019) Leguminous pre-crops improved quality of organic winter and spring cereals. Biol Agric Hortic 35:46-60. https://doi.org/10.1080/01448765.2018.1509728

19. Jain NK, Jat RS, Meena HN, Chakraborty K (2018) Productivity, nutrient, and soil enzymes influenced with conservation agriculture practices in peanut. Agron J 110:1165-1172. https://doi.org/10.2134/agronj2017.08.0467 
20. Kosteckas R, Marcinkevi A (2009) The integrated evaluation of the influence of catch crops and manure on spring barley agrocenosis in organic farming. 7:355-362

21. Kunze A, Dalla Costa M, Epping J et al (2011) Phosphatase Activity in Sandy Soil Influenced By Mycorrhizal and Non-Mycorrhizal Cover Crops (1) Divisão 2 -Processos E Propriedades Do Solo. Agric Extensionist Rua Henrique Kappke 35:705-711. https://doi.org/10.1590/S010006832011000300005

22. Kurola J, Salkinoja-salonen MS (2004) Areal activities and stratification of hydrolytic enzymes involved in the biochemical cycles of carbon, nitrogen, sulphur and phosphorus in podsolized boreal forest soils. 36:425-433. https://doi.org/10.1016/j.soilbio.2003.10.019

23. Milkvetch LAM C (2020) Nitrogen Fixation and Resource Partitioning in. 1-14

24. Li H, Shen J, Zhang F et al (2010) Phosphorus uptake and rhizosphere properties of intercropped and monocropped maize, faba bean, and white lupin in acidic soil. Biol Fertil Soils 46:79-91. https://doi.org/10.1007/s00374-009-0411-x

25. Li L, Tang C, Rengel Z, Zhang F (2003) Chickpea facilitates phosphorus uptake by intercropped wheat from an organic phosphorus source. 297-303

26. Lynch JP (2007) TURNER REVIEW No. 14 Roots of the Second Green Revolution. 493-512

27. Makoi JHJR, Bambara S, Ndakidemi PA (2010) Rhizosphere phosphatase enzyme activities and secondary metabolites in plants as affected by the supply of Rhizobium, lime and molybdenum in Phaseolus vulgaris L. Aust J Crop Sci 4:590-597

28. Maltais-Landry G, Frossard E (2015) Similar phosphorus transfer from cover crop residues and water-soluble mineral fertilizer to soils and a subsequent crop. Plant Soil 393:193-205. https://doi.org/10.1007/s11104-015-2477-6

29. Mandal UK, Singh G, Victor US, Sharma KL (2003) Green manuring: its effect on soil properties and crop growth under rice Á wheat cropping system. 19:225-237

30. Margalef O, Sardans J, Fernández-Martínez M et al (2017) Global patterns of phosphatase activity in natural soils. Sci Rep 7:1-13. https://doi.org/10.1038/s41598-017-01418-8

31. Mukumbareza C, Muchaonyerwa P, Chiduza C (2015) Effects of oats and grazing vetch cover crops and fertilisation on microbial biomass and activity after five years of rotation with maize. South African J Plant Soil 32:189-197. https://doi.org/10.1080/02571862.2015.1025446

32. Nelson DW (1996) Chap. 34 Total Carbon. Organic Carbon, and Organic Matter

33. Nelson DW, Sommers LE (1973) Determination of Total Nitrogen in Plant Material 1. 1-4

34. Noack SR, Ester P (2014) Crop residue phosphorus. Speciation and release in cropping soils

35. Nuruzzaman M, Lambers H, Bolland MDA, Veneklaas EJ (2005) Phosphorus benefits of different legume crops to subsequent wheat grown in different soils of Western Australia. 175-187. https://doi.org/10.1007/s11104-004-2386-6

36. Piotrowska-Długosz A, Wilczewski E (2014) Changes in enzyme activities as affected by greenmanure catch crops and mineral nitrogen fertilization. Zemdirbyste 101:139-146. 
https://doi.org/10.13080/z-a.2014.101.018

37. Prajapati K (2016) THE IMPORTANCE OF POTASSIUM IN PLANT GROWTH - A REVIEW THE IMPORTANCE OF POTASSIUM IN PLANT GROWTH - A REVIEW

38. Qi Z, Spalding EP (2015) Protection of Plasma Membrane K + Transport by the Salt Overly Sensitivel $\mathrm{Na}+-\mathrm{H}+$ Antiporter during Salinity Stress1. 136:2548-2555.

https://doi.org/10.1104/pp.104.049213.et

39. Richardson AE, Lynch JP, Ryan PR et al (2011a) Plant and microbial strategies to improve the phosphorus efficiency of agriculture. Plant Soil 349:121-156. https://doi.org/10.1007/s11104-0110950-4

40. Richardson AE, Lynch JP, Ryan PR et al (2011b) Plant and microbial strategies to improve the phosphorus efficiency of agriculture. 121-156. https://doi.org/10.1007/s11104-011-0950-4

41. Roldán A, Caravaca F, Hernández MT, Garc C (2003) No-tillage, crop residue additions, and legume cover cropping effects on soil quality characteristics under maize in Patzcuaro watershed (Mexico). 72:65-73. https://doi.org/10.1016/S0167-1987(03)00051-5

42. Saiya-Cork KR, Sinsabaugh RL, Zak DR (2002) The effects of long term nitrogen deposition on extracellular enzyme activity in an Acer saccharum forest soil. Soil Biol Biochem 34:1309-1315. https://doi.org/10.1016/S0038-0717(02)00074-3

43. Samarajeewa KBDP, Horiuchi T, Oba S et al (2015) Effect of Chinese Milk Vetch (Astragalus sinicus L.) as a Cover Crop on Weed Control, Growth and Yield of Wheat under Different Tillage Systems Effect of Chinese Milk Vetch (Astragalus sinicus L .) as a Cover Crop on Weed Control, Growth and Yield of. 1008:. https://doi.org/10.1626/pps.8.79

44. Shin R (2014) Strategies for improving potassium use efficiency in plants. Mol Cells 37:575-584. https://doi.org/10.14348/molcells.2014.0141

45. Sial TA, Liu J, Zhao Y et al (2019) Co-application of milk tea waste and NPK fertilizers to improve sandy soil biochemical properties and wheat growth. Molecules 24:1-17. https://doi.org/10.3390/molecules24030423

46. Sinsabaugh RL, Gallo ME, Lauber $C$ et al (2005) Extracellular enzyme activities and soil organic matter dynamics for northern hardwood forests receiving simulated nitrogen deposition. Biogeochemistry 75:201-215. https://doi.org/10.1007/s10533-004-7112-1

47. Soonl YK, Kalra YP (1994) SHORT COMMUNICATION A comparison of plant tissue digestion methods for nitrogen and phosphorus analYses. 2:243-245

48. Station AE (1962) ABSORPTION OF POTASSIUM AND RUBIDIUM FROM T H E SOIL BY CORN R O $O$ T S *. 243-244

49. Sujatha DV, Kavitha P, Naidu MVS (2017) Influence of Green Manure and Potassium Nutrition on Soil Potassium Fractions and Yield of Rice Crop. Int J Curr Microbiol Appl Sci 6:13-23. https://doi.org/10.20546/ijcmas.2017.611.002

50. Trust NP (2014) Antifungal. 123:99-105 
51. Vance CP, Uhde-Stone C, Allan DL (2003) Phosphorus acquisition and use: Critical adaptations by plants for securing a nonrenewable resource. New Phytol 157:423-447. https://doi.org/10.1046/j.1469-8137.2003.00695.x

52. Vierheilig H, Bennett R, Kiddle G et al (2000) Differences in glucosinolate patterns and arbuscular mycorrhizal status of glucosinolate-containing plant species. New Phytol 146:343-352. https://doi.org/10.1046/j.1469-8137.2000.00642.x

53. Wallenius K, Rita H, Mikkonen A et al (2011) Effects of land use on the level, variation and spatial structure of soil enzyme activities and bacterial communities. Soil Biol Biochem 43:1464-1473. https://doi.org/10.1016/j.soilbio.2011.03.018

54. White CM, Weil RR (2011) Forage radish cover crops increase soil test phosphorus surrounding radish taproot holes. Soil Sci Soc Am J 75:121-130. https://doi.org/10.2136/sssaj2010.0095

55. White CM, Weil RR (2010) Forage radish and cereal rye cover crop effects on mycorrhizal fungus colonization of maize roots. 507-521. https://doi.org/10.1007/s11104-009-0131-x

56. White PJ, George TS, Gregory PJ et al (2013) Matching roots to their environment. 207-222. https://doi.org/10.1093/aob/mct123

57. Yang K, Zhu J, Yan Q, Zhang J (2012) Soil enzyme activities as potential indicators of soluble organic nitrogen pools in forest ecosystems of Northeast China To cite this version: HAL Id : hal00930847 Soil enzyme activities as potential indicators of soluble organic nitrogen pools in fores. https://doi.org/10.1007/s13595-012-0198-z

\section{Figures}



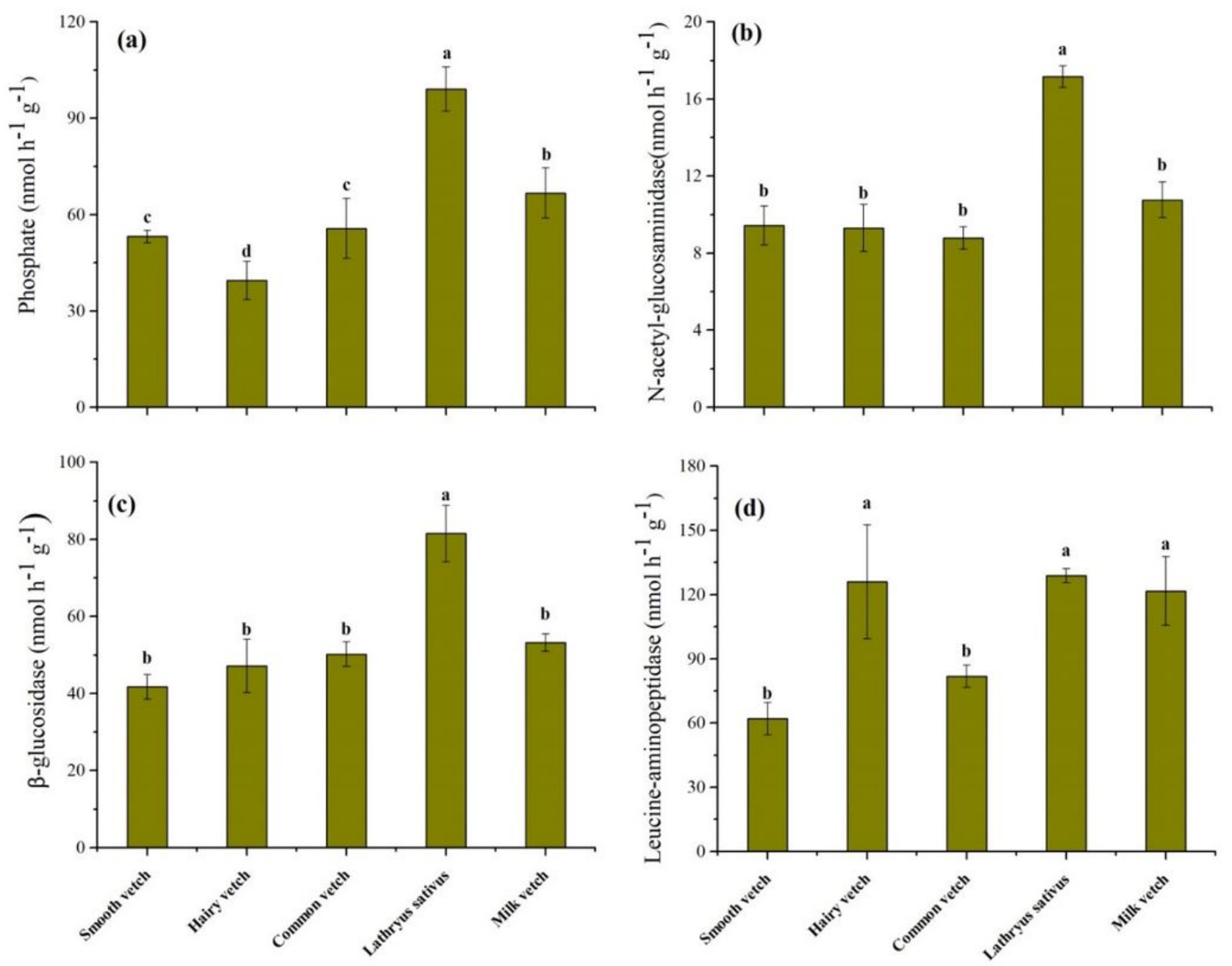

Figure 1

Influences of legume cultivar on enzyme activities: phosphatas (a), N-acetylglucosaminidase (b), $\beta$ glucosidase (c) and leucine-aminopeptidase (d). The letters showed significant influences $(p<0.05)$ by Duncan tests 

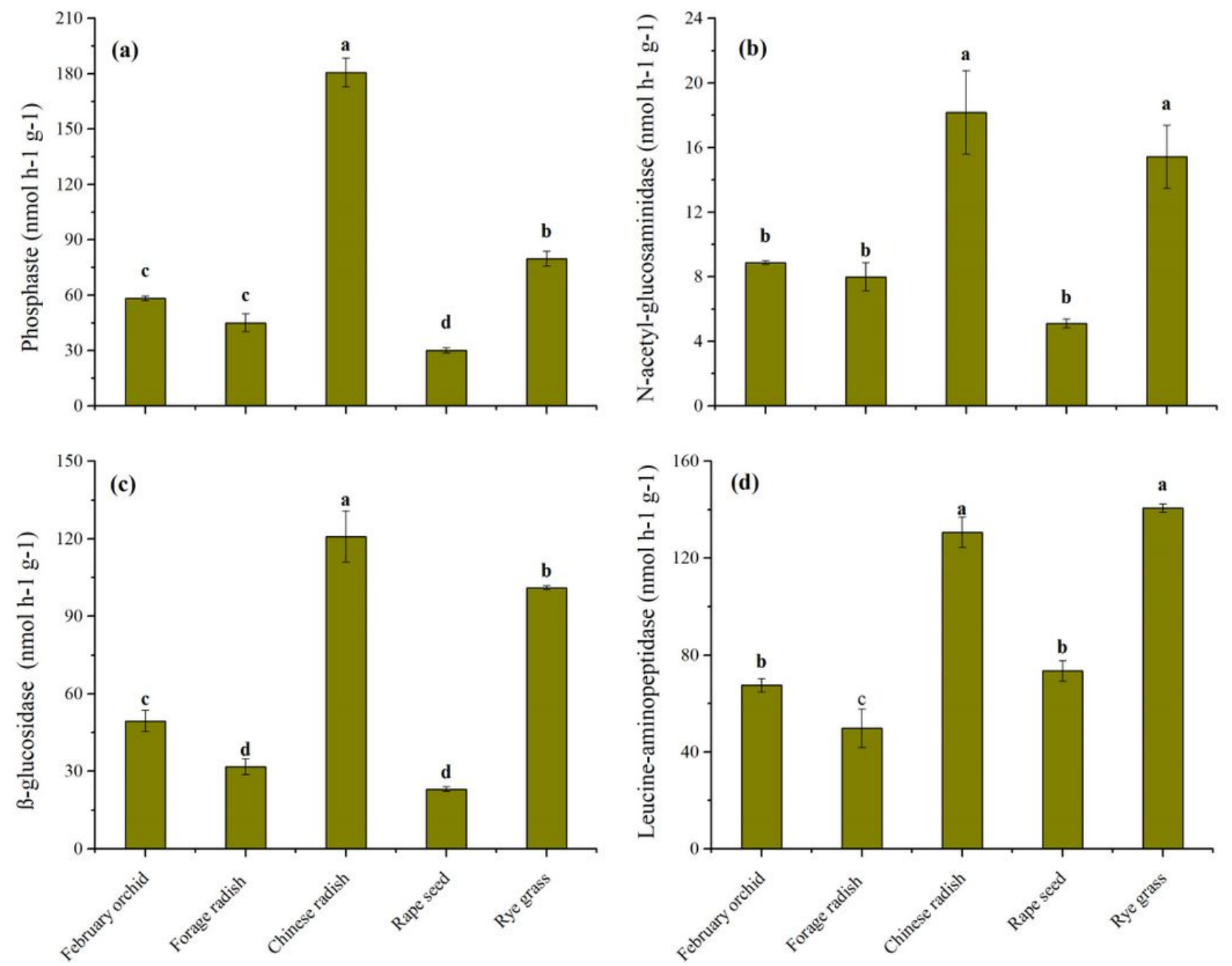

Figure 2

Influences of non-legume varieties on enzymatic activities: phosphatase (A), N-acetylglucosaminidase (B), $\beta$-glucosidase (C) and leucine-aminopeptidase (D). Different letters show significant influences ( $p<$ 0.05) using Duncan tests 
Rapseed $\square$ Hairy vetch $\nabla$ Chinese radish $>$ Smooth vetch $\square$ Common vetch $\uparrow$ February orchard $\Delta$ Forage radish $\odot$ Ryegrass $\bigcirc$ Milk vetch 4 Lathyrus
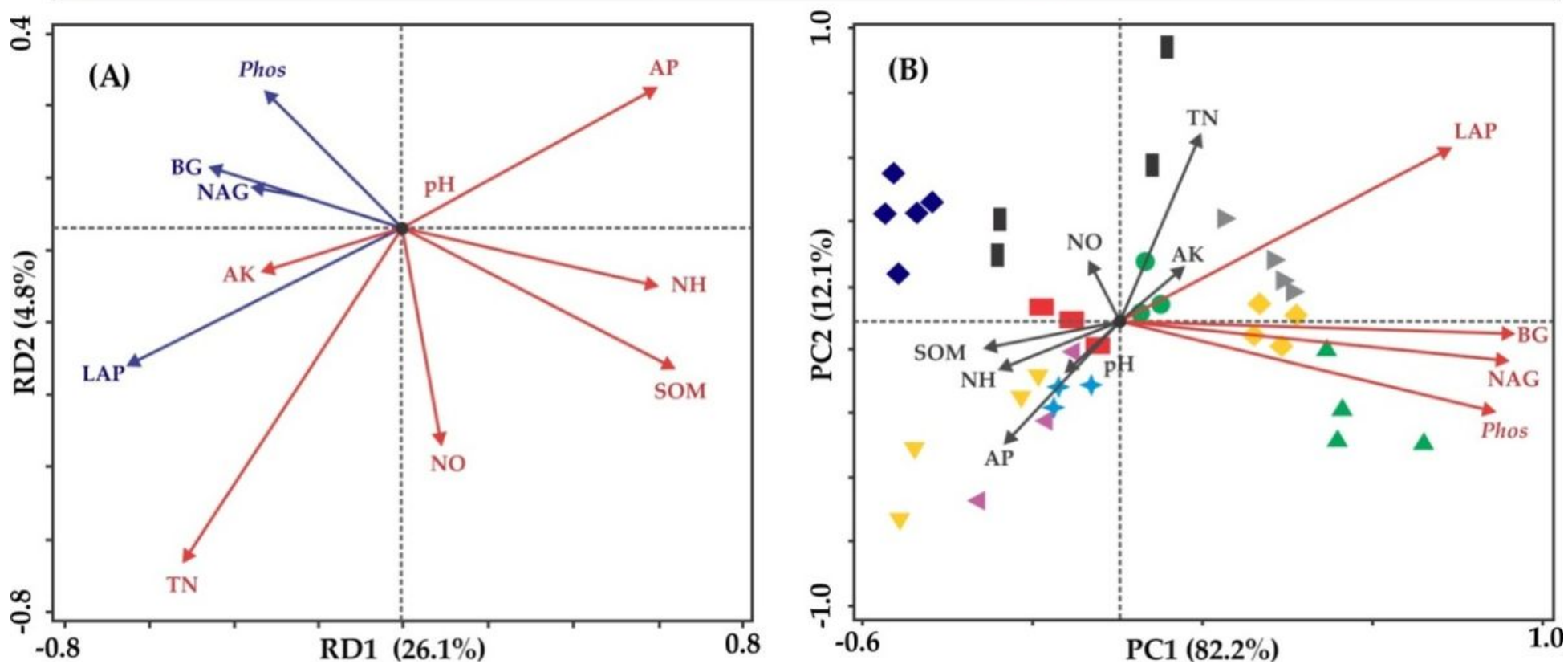

Figure 3

(A): Redundancy analysis (RDA) indicates the relationship between activities of enzymes and soil properties. (B): Principal component analysis (PCA) showed correlation among green manure treatments and soil properties. Note: Phosphatase (Phos), N-acetylglucosaminidase (NAG), $\beta$-glucosidase (BG), and leucine-aminopeptidase (LAP) are significantly correlated with soil properties; SOM (organic matter), TN (total nitrogen), ammonia (NH4+), nitrite (NO3-) mineral , available phosphorus (AP), available potassium (AK) and $\mathrm{pH}($ soil $\mathrm{pH})$ 